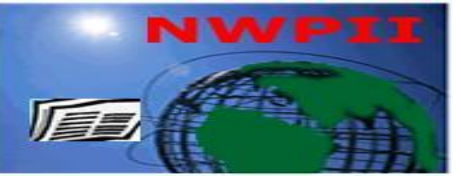

American Journal of Biomedical Sciences

ISSN: 1937-9080

nwpii.com/ajbms

\title{
Rheum emodi Induces Nitric Oxide Synthase Activity in Murine Macrophages
}

Fozia Kounsar and Zargar M Afzal*

\author{
* Department of Biochemistry, University of Kashmir, Srinagar \\ * Corresponding Author \\ Dr. Zargar M Afzal \\ Reader/Associate Professor \\ Department of Biochemistry, \\ University of Kashmir, Srinagar \\ India, 190011
}

Received: 2 July 2009; | Revised: 16 August 2009; | Accepted: 13 January 2010

\begin{abstract}
Rheum emodi has been traditionally used to treat pathological ailments like fevers, ulcers, bacterial infections, fungal infections, jaundice and liver disorders. Some workers have worked out anti-tumour activity of Rheum emodi but very little is known about the mechanisms involved. In the present studies we have evaluated the effects of Rheum emodi rhizome extract on signal pathways on expression of iNOS gene and release of NO in murine macrophage RAW 264.7 cell line. The studies could pave the way for understanding some of the treatment principles of the plant extract. The data indicate that Rheum emodi may have an immuno-enhancing effect through the release of various cytokines.
\end{abstract}

Keywords: Rheum emodi; anti-inflammatory; Nitric oxide; IL-12; IL-10; TNF- $\alpha$.

\section{Introduction}

Over recent decades, a substantial body of the evidence has demonstrated a wide range of pharmacological activities for a number of medicinal herbs. In addition, the investigation of the crude plant extracts through ethanopharmocological evaluations of plants with folk medicinal value, showed that a number of plants exhibit medicinal properties which may include antioxidant, anti-inflammatory and antitumour activities $(1,2)$. The presence of various compounds like flavonoids, polyphenolics, sesquiterpenoids, tannins and steroids have been implicated in a number of medicinal properties of the plants $(3,4,5)$.

Rheum emodi, Pambchallan (Kashmiri) has been traditionally used to treat pathological ailments like fevers, ulcers, bacterial infections, fungal infections, jaundice and liver disorders (6, $7,8,1)$. Some workers have worked out antitumour activity of Rheum emodi (9) but very little is known about the mechanisms involved. In the present studies we shall be evaluating the activity of Rheum emodi rhizome extract by conducting in vitro studies. The studies include effects on signal 
transduction parameters that could pave the way for understanding some of the treatment principles of the plant extract.

It is an established fact that macrophages are involved in many different processes such as tissue remodeling during embryogenesis, wound healing, removal of damaged or senescent cells subsequent to injury or infection, and provide a line of defense against microbial invasion, recognize and kill tumour cells. Macrophages exhibit these immunomodualtory functions through the release of reactive oxygen species including NO, TNF- $\alpha$ and various cytokines like IL-10, IL-12, IL-4 etc (10).

\section{Materials and methods}

\subsection{Plant material collection}

Rheum emodi Wall. ex Meisn was collected from higher reaches of Kongdoori Gulmarg in the month of May-June at an altitude of 3000m (a.s.1) The plant was identified at the Centre of Plant Taxonomy, Department of Botany, University of Kashmir using standard references and authenticated by a botanist Dr. Irshad Ahmad Nawchoo. The voucher specimen was deposited under herbarium no: (Kash-bot/Ku/Rh-Fz-03) at the centre. The rhizome part was cut and washed with water. The rhizome was then allowed to dry at room temperature.

\subsection{Plant Extraction}

Extraction of dried plant material was carried out using a method described by Harborne (11). When the plant material (rhizome) dries up then it was grinded using motar and pestle. $500 \mathrm{gm}$ of the rhizome was put into the thimble of the soxhlet (Fisher Scientific, Germany). 100ml of 50\% ethyl acetate $(\mathrm{BDH})$ was added and extracted at 60 $90^{\circ} \mathrm{C}$ for three hours. The fraction was collected and stored for bioassay.

The plant extract was filtered through various layers of muslin cloth. The solvent was evaporated under the rotary vacuum evaporator and the residue was estimated to yield $20 \mathrm{gm}$ of reddish plant powder. Plant extract was redissolved in water using standard procedure. Plant extract was treated with polymyxine $10 \mu \mathrm{g} / \mathrm{ml}$ (Sigma) overnight at $4^{\circ} \mathrm{C}$ to remove any lipopolysaccharide (LPS) contamination. Then extract was centrifuged at 5,000rpm for $5 \mathrm{~min}$ and filtered with $0.2 \mu \mathrm{M}$ filter (Millipore) and stored at $-20^{\circ} \mathrm{C}$ until needed. Before use plant extract was tested for any LPS content using an E-TOXATE assay kit (Sigma) with detection limit of $0.25 \mathrm{EU} / \mathrm{ml}$.

\subsection{DMEM medium preparation}

Formulation is based on the Dulbecco's Modified Eagle's Medium (GIBCO, USA) having high glucose with L-glutamine and pyridoxine hydrochloride with sodium pyruvate. $3.7 \mathrm{gm}$ sodium bicarbonate was added per liter of DMEM and the $\mathrm{pH}$ was maintained at 7.3 with $1 \mathrm{~N} \mathrm{HCl}$. The prepared DMEM was filtered under sterile conditions through $0.22 \mu \mathrm{M}$ filtering units (Nalgene, USA) and the media was checked for any contamination by incubations at room temperature for $24 \mathrm{hrs}$. Finally 10\% FBS (foetal bovine serum, GIBCO, USA) and $1 \%$ antibiotic (Gibco, USA) were finally added to prepare a complete media

\subsection{Cell line}

For in vitro studies mouse macrophage cells (RAW 264.7) were used. The RAW 264.7 macrophages were obtained from National Centre for Cell Science, Pune, India and maintained in complete Dulbecco's Minimal Essential Medium (DMEM, GIBCO BRL, USA). The culture flasks were kept at $37^{\circ} \mathrm{C}$ in $5 \% \mathrm{CO}_{2}$ incubator.

\subsection{Measurement of nitrite (NO) concentration}

The macrophages were plated at a density of $3 \times 10^{5}$ cells per well and stimulated with a combination of $5 \mu \mathrm{g} / \mathrm{ml}$ of lipopolysaccharide (LPS, Sigma-Aldrich, St. Louis, MO) and 3ng/ml of interferon-gamma (IFN- $\gamma, \mathrm{R} \& \mathrm{D}$ Systems, Minneapolis, MN) in the absence or presence of various concentrations of plant extract. After 48 hours of stimulation, the culture supernatants were harvested for the estimation of NO. To measure the nitrite, $100 \mu \mathrm{l}$ of supernatant was incubated with the equal volume of Griess reagent (1\% 
(W/V) sulfanilamide, $0.1 \% \quad(\mathrm{~W} / \mathrm{V})$ napthylethylenediamine hydrochloride and $2.5 \%$ (V/V) $\mathrm{H}_{3} \mathrm{PO}_{4}$ ) at room temperature for $10 \mathrm{~min}$. The nitrite reacts with Griess reagent and forms purple azo dye, which can be detected spectrophotometerically at $540 \mathrm{~nm}$ in Ultra Microplate Reader (BIO-TEK INSTRUMENT) (12). Concentration of NO was extrapolated from the standard $\mathrm{NaNO}_{2}$ curve.

The levels of IL-10, IL-12p40 and TNF$\alpha$ were also checked by two-site sandwich enzyme immuno assay (EIA) in the supernatant as described by Mukhopadhyay (13). Standard curve for each cytokine was obtained using the recombinant standard proteins as provided by the manufacturer (BD Biosciences Pharmingen, San Diego, CA, USA).

\subsection{Whole cell extract preparation}

Whole cell extract was prepared following procedure described earlier (14). RAW 264.7 cells were seeded in 6well plate (corning USA) at the density of $5 \times 10^{6}$ cells /well. Cells were either left unstimulated (US) which serves as media control ,or cells are stimulated with LPS+IFN- $\gamma(\mathrm{S})$ which serves as positive control, or the cells are stimulated with the extract $(100 \mu \mathrm{g} / \mathrm{ml})$, extract $+\mathrm{S}$ $(100 \mu \mathrm{g} / \mathrm{ml}$, LPS + IFN- $\gamma)$ and extract + PDTC $(200 \mu \mathrm{M})$. Incase of pyrrolidine dithiocarbamate (PDTC) treatment; cells were first treated with $200 \mu \mathrm{M}$ PDTC for $1 \mathrm{hr}$ at $37^{\circ} \mathrm{C}$. Then extract was added at the conc. of $100 \mu \mathrm{g} / \mathrm{ml}$ in the respective set and again incubated for $1 \mathrm{hr}$, followed by stimulation with LPS+IFN $\gamma$ in the respective set. After incubation for further $1 \mathrm{hr}$ at $37^{\circ} \mathrm{C}$, the cells from each set were scrapped and pelleted at 5,000 $\mathrm{rpm}$ at $4^{\circ} \mathrm{C}$. After washing with ice cold phosphate buffered saline (PBS) thrice at $4^{\circ} \mathrm{C}$, the cells were pelleted at 5,000 rpm for 5 minutes at $4^{\circ} \mathrm{C}$. To each set of pellet $200 \mu$ l of whole cell lysis buffer was added.The pellet was resuspended in the lysis buffer by hard vortexing for $5 \mathrm{~min}$. The cells were lysed completely by passing through $1 \mathrm{ml}$ syringe various times and finally lysate was centrifuged at $10,000 \mathrm{rpm}$ for 5min. Supernatant collected contained all the cellular proteins. Protein concentration for each set was estimated by BCA (Pierce, USA) along with known standard. 50 $\mu \mathrm{g}$ of protein from each set was analyzed on SDS PAGE along with prestained protein marker and further processed for western blot analysis for iNOS expression after treatment with the Rheum emodi extract by western blotting.

\subsection{Western Blotting}

The proteins were resolved on a denaturing SDS-PAGE gel and after completion of the run the gel was over layered by a nitrocellulose membrane (Amersham BioSciences, Santa Cruz, CA) and kept inside the blotting cassette in the presence of blotting buffer. The cassette was put inside the complete wet transfer apparatus (Bio Rad, USA) and transfer was allowed for $4 \mathrm{hrs}$ at a constant voltage of $60 \mathrm{~V}$. The blot was taken and blocked with 5\% non-fat milk solution in PBS with a gentle shaking for $3 \mathrm{hr}$ at $37^{\circ} \mathrm{C}$. The blot was washed thoroughly with phosphate buffered saline with $0.1 \%$ tween (PBS-T) and PBS five times. The blot was over layered with the primary antibody against anti-mouse iNOS (Sigma) for 1 hour at $4^{\circ} \mathrm{C}$ with gentle shaking. After incubation the membrane was washed with PBS-T and followed by PBS 5 times. Blot was then again probed with secondary antibody anti-rabbit immunoglobulinhorse radish peroxidase (Ig-HRP) conjugate (Sigma, USA). The secondary antibody is prepared in diluted in $1 \%$ fat free milk solution in PBS and incubated for 45 minutes at room temperature. After incubation the blot was washed and processed for the protein bands of interest using ECL-plus detection reagent (Amersham Biosciences, UK) followed by development of the bands using X-ray film (Hyperfilm-ECL, Amersham Biosciences). The blot was kept in developer for $2 \mathrm{~min}$ and then fixed the blot by leaving the blot in fixer for some time. The blot was washed with water twice and allowed to dry. The blot was then stained with the ponceau stain to confirm equal loading of protein in each well.

\subsection{Statistical Analysis:}

Statistical evaluation of the results was performed using ANOVA with the Turkey post hoc test. The data represents the mean of three different experiments and was proven statistically significant. The standard error of mean (S.E.M) is less i,e $\mathrm{P}<0.001$.

(c) 2010 by NWPII. All rights reserved. 


\section{Results}

In RAW264.7cells the effect of plant extract on NO production was estimated using standard procedures. As observed in Figure 1 dose dependent increase in the NO production by the RAW264.7 cells is observed when exposed to ethyl acetate extract of Rheum emodi. In the presence of the stimulant, $5 \mu \mathrm{g} / \mathrm{ml}$ LPS $+3 \mathrm{ng} / \mathrm{ml}$ IFN- $\gamma$, the nitric oxide level was increased to $55 \mu \mathrm{M}$ which however was increased to $60 \mu \mathrm{M}$, $65 \mu \mathrm{M}, 68 \mu \mathrm{M}$ respectively in the presence of $25 \mu \mathrm{g} / \mathrm{ml}, 50 \mu \mathrm{g} / \mathrm{ml}$ and $100 \mu \mathrm{g} / \mathrm{ml}$ concentrations of the extracts. Extract alone did also result in the dose dependent increase in the production of the NO.

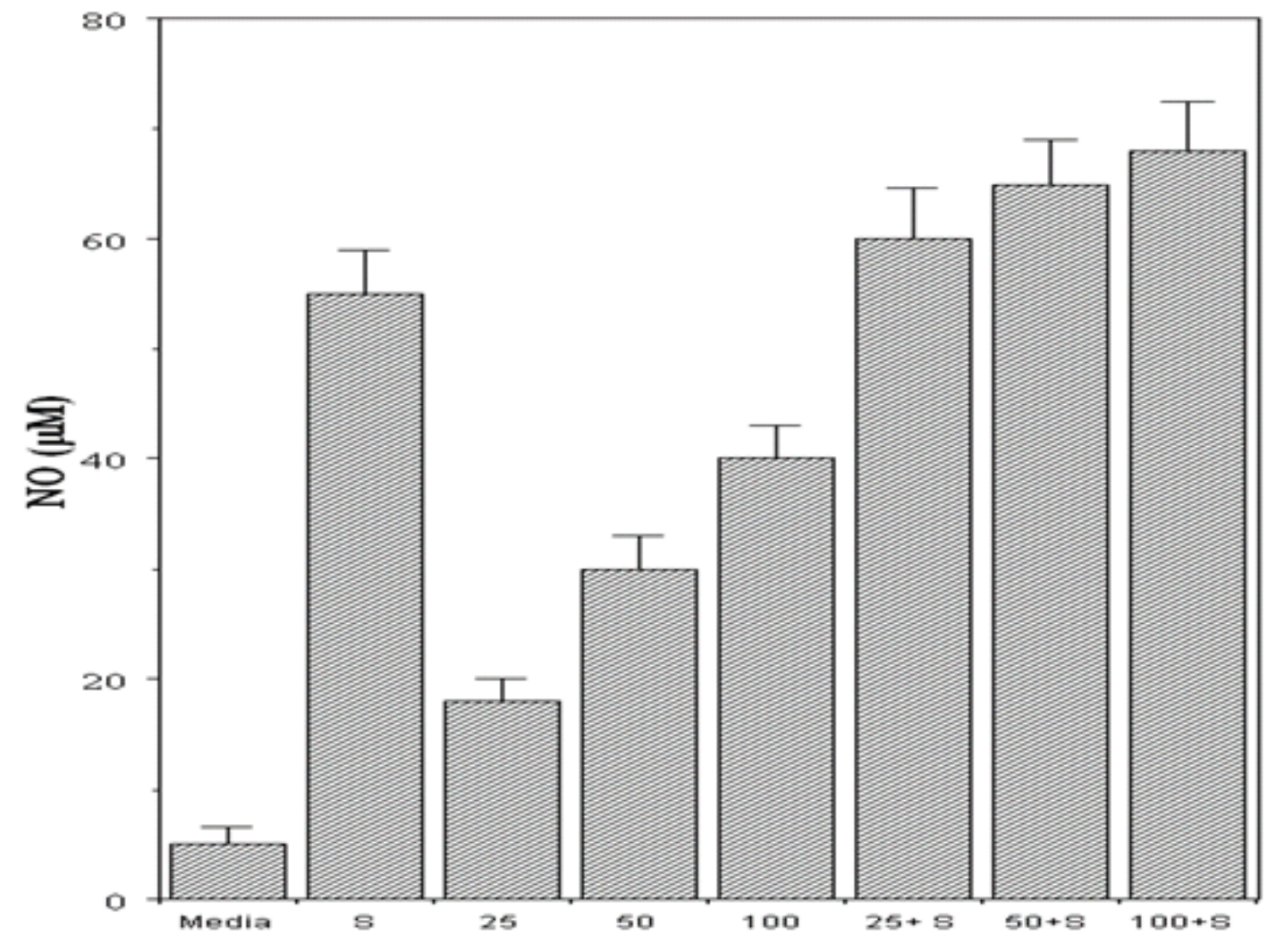

Figure 1

Figure 1. Effect of ethyl acetate extract of Rheum emodi on NO release by RAW 264.7 cells. LPS+IFN$\gamma(5 \mu \mathrm{g} / \mathrm{ml}+3 \mathrm{ng} / \mathrm{ml})$ was used as stimulant. Concentrations of extract used in the experiment is $25 / 50 / 100 \mu \mathrm{g} / \mathrm{ml}$ alone or in combination with the stimulant. The data represents the mean of three different experiments and was proved statistically significant. The standard error of mean (S.E.M) is less i.e $\mathrm{P}<0.001$.

\subsection{Rheum emodi induced activation of iNOS expression}

Pursuant to the observation that Rheum emodi extract increases the NO production from RAW 264.7 murine macrophages in a dose dependent manner, the level of expression of enzyme iNOS which catalyses the downstream reaction for NO production was studied. Four different experimental sets were used as unstimulated cells or media control, cells stimulated with stimulant LPS $(5 \mu \mathrm{g} / \mathrm{ml})$ and IFN- $\gamma(3 \mathrm{ng} / \mathrm{ml})$, cells stimulated with ethyl extract of Rheum emodi $(100 \mu \mathrm{g} / \mathrm{ml})$, and cells stimulated followed by treatment with ethyl extract of Rheum emodi $(100 \mu \mathrm{g} / \mathrm{ml})$ were used. The whole cell extract was assayed for the iNOS expression by the immunoblotting analysis. As shown in Figure 2a, a basal level of iNOS was observed in unstimulated cells. When the cells 
were treated with stimulant $(5 \mu \mathrm{g} / \mathrm{ml}$ LPS, IFN- $\gamma$ $3 \mathrm{ng} / \mathrm{ml}$ ), iNOS expression was induced above basal level. The protein band analysis showed that plant extract increased the iNOS expression alone as well as in the presence of stimulant as shown in Figure 2a. (a)

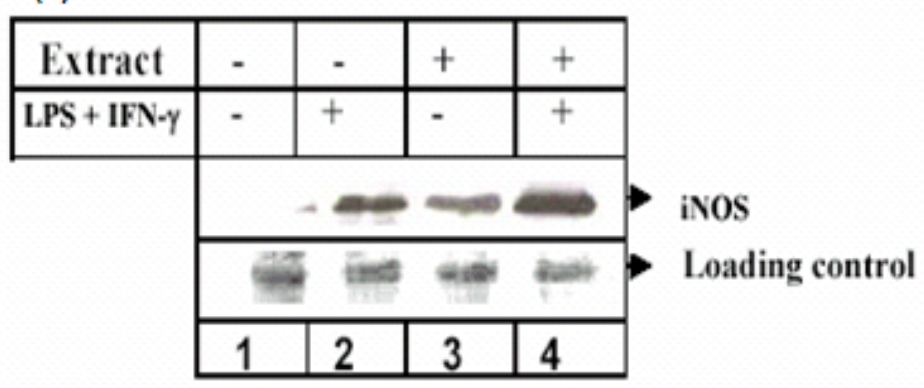

(b)

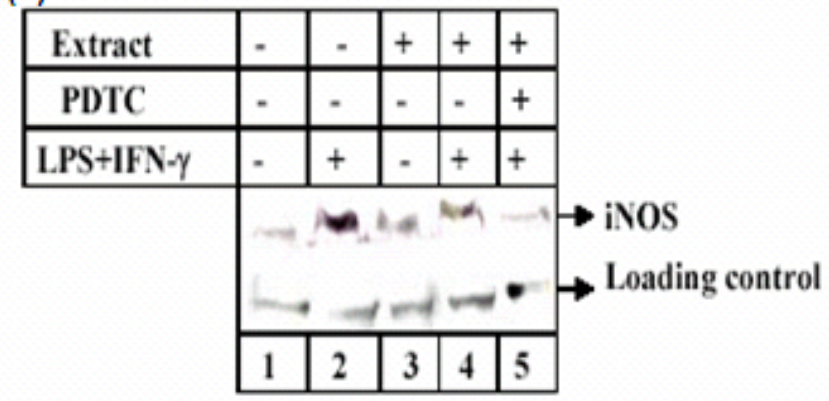

(c)

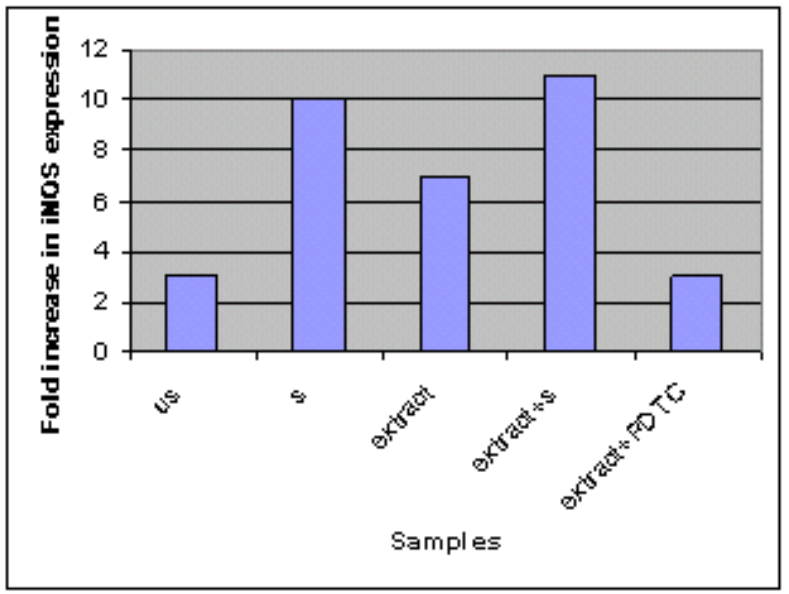

Figure 2

Figure 2a. Effect of ethyl acetate extract of Rheum emodi on signalling pathways on expression of iNOS in RAW 264.7 cells. Lane 1, represents Whole cell extract prepared from control (unstimulated cells). Lane 2, represents stimulated cells $(5 \mu \mathrm{g} / \mathrm{ml} \mathrm{LPS}$, IFN- $\gamma 3 \mathrm{ng} / \mathrm{ml})$. Lane 3, represents $100 \mu \mathrm{g} / \mathrm{ml}$ ethyl acetate extract of Rheum emodi and Lane 4, represents $100 \mu \mathrm{g} / \mathrm{ml}$ ethyl acetate extract of Rheum emodi in presence of stimulant. Ponceau S staining of the membrane confirms equal loading of nuclear extract. All lanes contained $50 \mu \mathrm{g}$ of total protein. The experiment was repeated three times with similar results.

Figure 2b. Effect of ethyl acetate extract of Rheum emodi on signalling pathways on expression of iNOS in presence of PDTC in RAW 264.7 cells. Lane 1, represents Whole cell extract prepared from control (unstimulated cells). Lane 2, represents stimulated cells $(5 \mu \mathrm{g} / \mathrm{ml} \mathrm{LPS}$, IFN- $\gamma 3 \mathrm{ng} / \mathrm{ml})$. Lane 3, represents $100 \mu \mathrm{g} / \mathrm{ml}$ ethyl acetate extract of Rheum emodi. Lane 4, represents $100 \mu \mathrm{g} / \mathrm{ml}$ ethyl acetate extract of Rheum emodi in presence of stimulant and Lane 5, represents cells treated with PDTC. All lanes contained $50 \mu \mathrm{g}$ of total protein. Ponceau S staining of the membrane confirms equal loading of nuclear extract. The experiment was repeated three times with similar results.

Figure 2c. Effect of ethyl acetate extract of Rheum emodi increases the iNOS expression .The data represents the increased expression of iNOS in terms of fold induction in control (unstimulated cells), stimulated cells $(5 \mu \mathrm{g} / \mathrm{ml} \mathrm{LPS}$, IFN- $\gamma 3 \mathrm{ng} / \mathrm{ml}), 100 \mu \mathrm{g} / \mathrm{ml}$ ethyl acetate extract of Rheum emodi fraction in presence of stimulant and in presence of inhibitor PDTC $(200 \mu \mathrm{M})$.

When the effects of the extract and stimulant was studied in the presence of $200 \mu \mathrm{M}$ of PDTC a known inhibitor of $\mathrm{NF \kappa B}$, it resulted in the inhibition of iNOS expression to unstimulated level as shown in Figure $2 b$. The fold increase calculated by scanning the blots in Quantity One 
software (Bio-Rad) show that ethyl acetate fraction of Rheum emodi increases the expression of iNOS by three-fold. The ethyl acetate extract in combination with stimulant increases the iNOS expression by more then three fold, but the extract in combination with PDTC brings decrease in the iNOS expression to the basal levels as shown in Figure 2c.

\subsection{Rheum emodi activates the immune response in RAW 264.7 cells}

The study of immuno-modulatory effect of the Rheum emodi extracts were focused on the ethyl acetate extracts only. Activation of various cytokines on RAW 264.7 cell lines were studied in the presence and absence of the ethyl acetate extract to infer their immunomodulatory role and suggest some plausible mechanism of action. Four groups, unstimulated (US) as (-ve) control, or cells stimulated with LPS+IFN $-\gamma(\mathrm{S})$ as (+ve) control,
Extract alone and Extract $+\mathrm{S}$ were used in our all further experimental approaches to analyze the results of the Rheum emodi extract in relation with the positive as well as negative controls taken under same experimental conditions.

The effect of plant extract on TNF- $\alpha$, IL-10 and IL-12 p40 production was estimated using standard procedures. The effect of ethyl acetate on the production of TNF- $\alpha$ is shown in Figure 3. In the presence of the stimulant, $5 \mu \mathrm{g} / \mathrm{ml}$ LPS $+3 \mathrm{ng} / \mathrm{ml}$ IFN- $\gamma$, TNF- $\alpha$ level was increased to $305 \mathrm{ng} / \mathrm{ml}$. Ethyl acetate extract alone at concentrations of $25 \mu \mathrm{g} / \mathrm{ml}, 50 \mu \mathrm{g} / \mathrm{ml}, 100 \mu \mathrm{g} / \mathrm{ml}$ resulted in the production of $65.5 \mathrm{ng} / \mathrm{ml}, 155 \mathrm{ng} / \mathrm{ml}$, $200 \mathrm{ng} / \mathrm{ml}$ of TNF- $\alpha$ which was concomitantly increased to $340 \mathrm{ng} / \mathrm{ml}, 398 \mathrm{ng} / \mathrm{ml}, 410 \mathrm{ng} / \mathrm{ml}$ respectively in the presence of the stimulant as shown in Figure 3.

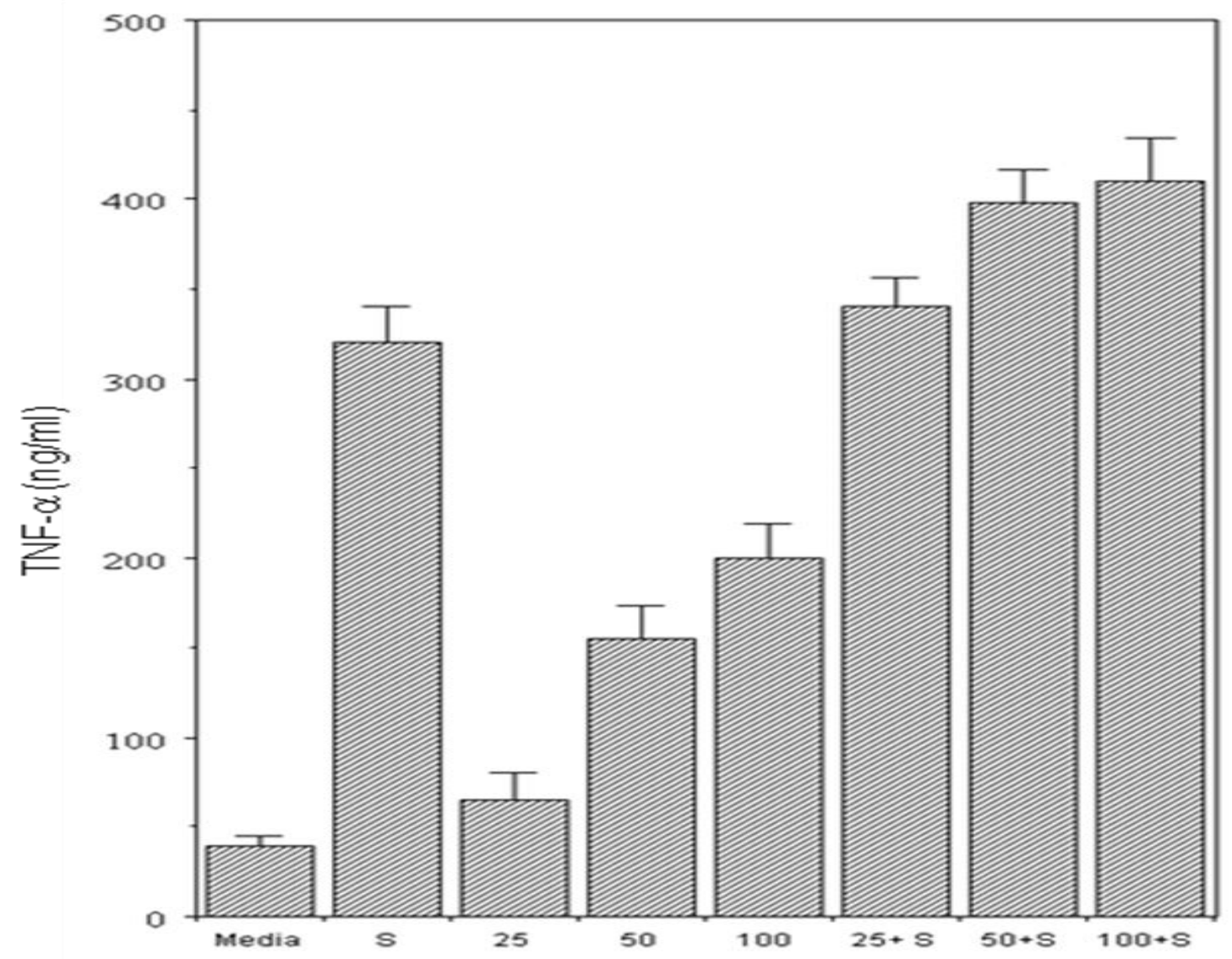

Figure 3. Effect of ethyl acetate extract of Rheum emodi on the TNF- $\alpha$ release by RAW 264.7 cells. LPS+IFN$\gamma(5 \mu \mathrm{g} / \mathrm{ml}+3 \mathrm{ng} / \mathrm{ml})$ was used as stimulant. Concentrations of extract used in the experiment is $25 / 50 / 100 \mu \mathrm{g} / \mathrm{ml}$ alone or in combination with the stimulant. The data represents the mean of three different experiments and was proved statistically significant. The standard error of mean (S.E.M) is less i.e $\mathrm{P}<0.001$. 
It is important to know which way the ethyl acetate extract of Rheum emodi shifts the immune balance, so various cytokines levels were checked from RAW 264.7 macrophages after stimulating with the ethyl acetate extract of Rheum emodi. As shown in Figure $4 a \& 4 b$, ethyl acetate extract distinctively exhibited a contrasting effect on the production of IL-10 and IL-12p40. A dose dependent increase of IL-12 p40 production was observed when the extract was used alone or in combination with the stimulant. Ethyl acetate extract alone at a concentration of $25 \mu \mathrm{g} / \mathrm{ml}$, $50 \mu \mathrm{g} / \mathrm{ml}, 100 \mu \mathrm{g} / \mathrm{ml}$ resulted in the production of $300 \mathrm{ng} / \mathrm{ml}, \quad 450 \mathrm{ng} / \mathrm{ml}, \quad 530 \mathrm{ng} / \mathrm{ml}$ of IL-12p40

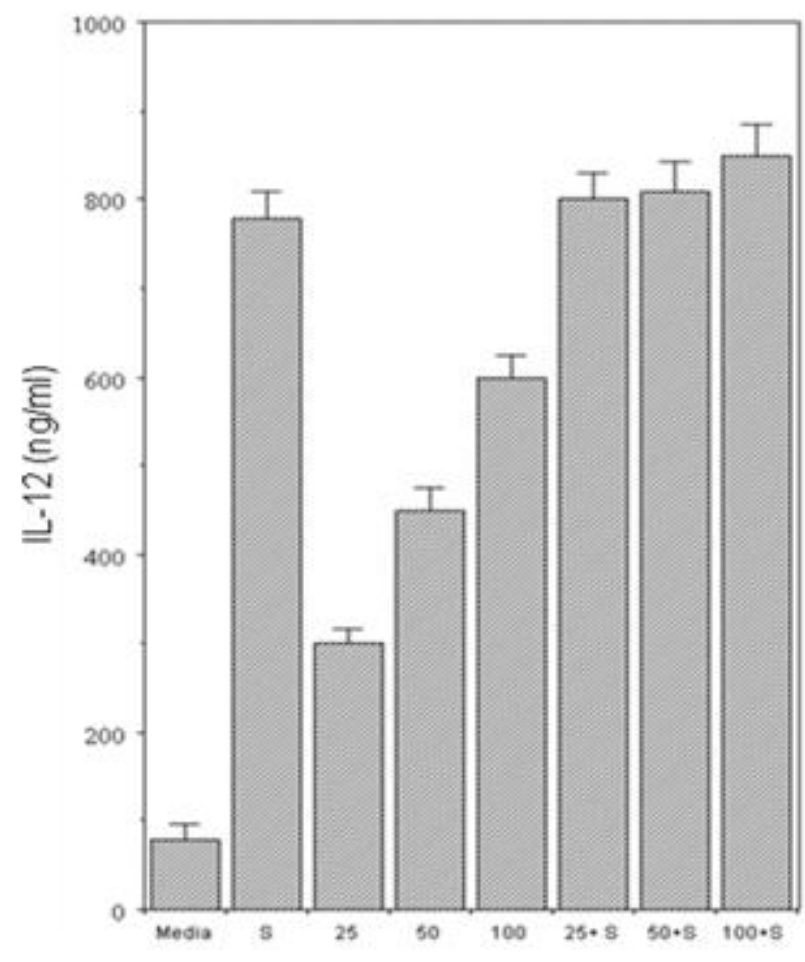

(a) which was concomitantly increased to $800 \mathrm{ng} / \mathrm{ml}$, $802 \mathrm{ng} / \mathrm{ml}, 850 \mathrm{ng} / \mathrm{ml}$ respectively in the presence of stimulant as shown in Figure 2a. As seen in Figure 2b, IL-10 levels are decreased in a dose dependent manner with increased concentrations of the plant extract. In the presence of the stimulant, $5 \mu \mathrm{g} / \mathrm{ml} \mathrm{LPS}+3 \mathrm{ng} / \mathrm{ml}$ IFN- $\gamma$, the IL-10 level was increased to $500 \mathrm{ng} / \mathrm{ml}$ which however was decreased to $390 \mathrm{ng} / \mathrm{ml}, 260 \mathrm{ng} / \mathrm{ml}$ and $165 \mathrm{ng} / \mathrm{ml}$ respectively in the presence of $25 \mu \mathrm{g} / \mathrm{ml}$, $50 \mu \mathrm{g} / \mathrm{ml}$ and $100 \mu \mathrm{g} / \mathrm{ml}$ concentrations of the extracts.

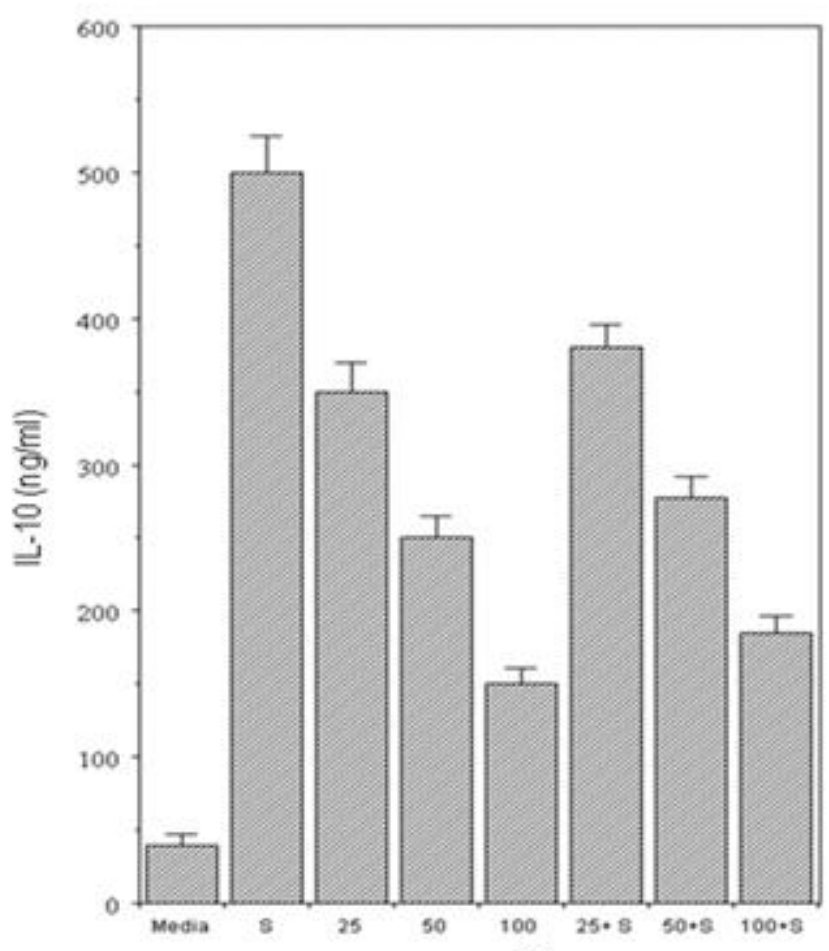

(b)

Figure 4

Figure 4a. Effect of ethyl acetate extract of Rheum emodi on the release of IL-12 by RAW 264.7 cells. LPS+IFN$\gamma(5 \mu \mathrm{g} / \mathrm{ml}+3 \mathrm{ng} / \mathrm{ml})$ was used as stimulant. Concentrations of extract used in the experiment is $25 / 50 / 100 \mu \mathrm{g} / \mathrm{ml}$ alone or in combination with the stimulant. The data represents the mean of three different experiments and was proved statistically significant. The standard error of mean (S.E.M) is less i.e $\mathrm{P}<0.001$.

Figure 4b. Effect of ethyl acetate extract of Rheum emodi on the release of IL-10 by RAW 264.7 cells. LPS+IFN$\gamma(5 \mu \mathrm{g} / \mathrm{ml}+3 \mathrm{ng} / \mathrm{ml})$ was used as stimulant. Concentrations of extract used in the experiment is $25 / 50 / 100 \mu \mathrm{g} / \mathrm{ml}$ alone or in combination with the stimulant. The data represents the mean of three different experiments and was proved statistically significant. The standard error of mean (S.E.M) is less i.e $\mathrm{P}<0.001$. 


\section{Discussion}

Recently, plant extracts have gained much more importance for their role in regulating the immune response. Rheum emodi extract is already known to have antitumour and wound healing activity $(6,1,9)$. Knowing that the macrophages play an important role in the wound healing process and also in the killing of microorganisms, Rheum emodi, a traditional wound healer was tested for modulations within macrophages. Ethyl acetate extract of Rheum emodi was tested for the study. Macrophages incubated with the Rheum emodi extracts expressed the high levels of iNOS and generates large amount of $\mathrm{NO}$ in dose dependent manner. Data infers that the Rheum emodi may be activating macrophages and generating NO affecting various intracellular parameters. NO is released at the minimum concentration of $25 \mu \mathrm{g} / \mathrm{ml}$.

The results further indicate that Rheum emodi extracts may be exerting its effect by inducing the iNOS expression as evidenced by up regulation of the iNOS expression in RAW 264.7 macrophages in the presence of ethyl acetate extract of Rheum emodi through Western blot analysis. The results are reversed in the presence of PDTC, an inhibitor of NF- $\kappa \mathrm{B}$ which is a well known regulator of iNOS expression.

Macrophages incubated with the ethyl acetate extract of Rheum emodi extracts expressed the high levels of iNOS and generates large amount of $\mathrm{NO}$ in dose dependent manner. Also the cells incubated with PDTC showed the decreased levels of NO, indicating the transcription factor NF- $\mathrm{KB}$ may be involved in the signaling pathway by plant extract. We know that the iNOS is under the control of transcription factor NF- $\kappa \mathrm{B}$. We can speculate that ethyl acetate extract of Rheum emodi extract probably targets the transcription $\mathrm{NF}-\kappa \mathrm{B}$ to show its effect on iNOS induction and subsequent production of IL-12 and TNF- $\alpha$. Complex mechanism is involved in the iNOS gene regulation and two NF- $\mathrm{KB}$ binding sites in the iNOS promoter are essential for iNOS transcription (15). The production of NO is the result of the induction and the gene expression of an iNOS enzyme present in the macrophages.
Some plant extracts have been shown to be $\mathrm{NO}$ inducers by different mechanisms $(16,17)$.

Plant extract is already known to have antibacterial, anticoagulating, anticancerous and wound healing activity. Our data suggest that it probably activates macrophages and generates $\mathrm{NO}$ along with other cytokines and these effects might be exerted through induction of the iNOS gene via transcription factor NF- $\mathrm{\kappa B}$.

It is speculated that the antibacterial, wound healing and antitumor activity of Rheum emodi ethyl acetate extract could also be due to activation of macrophages through augmentation in $\mathrm{NO}$ production and other cytokines by induction of iNOS gene expressions via transcription factor NF- $\mathrm{KB}$. Wound healing, a normal process, consists of four distinct but overlapping phases including Hemostatis, Inflammation, Proliferation and Remodeling. Hemostatis phase begins the moment tissue gets injured, platelets coming into direct contact with exposed collagen and other extracellular matrix. This contact triggers release of growth factors like PDGF, and TGF- $\beta$, and cytokines. The entry of neutrophils into the wound is followed by macrophages which aid in phagocytosis and further release of PDGF and TGF- $\beta$. The inflammatory stage is followed by granulation and within granulation, angiogensis by NO, VEGF and fibroblast growth factor-2. VEGF is known to be transcriptionally upregulated in response to $\mathrm{NO}$ (18).

Thus we could propose that our extract probably exerts directly by modulating various cytokines levels. Further NO being toxic to microbial cell growth may play a part in antibacterial activity exhibited by Rheum emodi and thus appears to have a potential therapeutic value for treating cancer, bacterial infection and promotion of wound healing process.

\section{References}

1. Borgia, M.; Sepe, N.; Borgia, R.; OriBellometti, M. Pharmacological activity of an herbal extract: controlled clinical study. Current Therapeutic Research. 1981, (29), 525-536. 
2. Heras, B. L.; Slowing, K.; Benedi, J.; Carretero, E.; Ortega,T.; Toledo, C.; Berm Iglesias, I. Anti-inflammatory and antioxidant activity of plants used in traditional medicine in Ecuador. Journal of Ethanopharmocology. 1998, (61)161-166.

3. Mc clure, J. W. Physiology and functions of flavonoids, Edited by Harborne JB and Mbry IJ. New York, Academic Press. 1975. pp: 970-1055.

4. Harborne, J. B and Baxter, H. Eds. The handbook of natural flavonoids. John Wiley \& Sons,Chichester. 1\&2. 1999. pp: 24-44.

5. Hertog, M. G. L. and Hollman, P. C. H. Potential health effects of the dietary flavanol quercetin. European Journal of Clinical Nutrition. 50. 1998. pp: 63-71.

6. Peirce A. The American Pharmaceutical Association practical guide to natural medicines. New York: William Morrow and Company, Inc. 1999.

7. Babu, K. S.; Srinivas, P.V.; Praveen, B.; Kishore, K. H.; Murty, U. S and Rao, J. M. Antimicrobial constituents from the rhizomes of Rheum emodi, Phytochem. 2003, (62). 203207.

8. Agarwal, S. K; S. Sudhir.; Singh S., Verma, S.; Kumar, S. Anti fungal activity of anthraquinone with derivatives from Rheum emodi. J. Ethnopharmacol. 2000, (72). 43-46.

9. Huang, Q.; Lu, G.; Shen, H. M.; Maxey, C. M.; Chung Choon, N. Anti-cancer properties of Anthraquinones from rhubarb. Medicinal Research Reviews. 2006 (27) pp: 609-630.

10. Adams,O. D and Hamilton, T. A. Molecular basis of macrophages activation and its origins. Oxford University Press, New York. 1992. pp: 75-114.
11. Harborne, J. B. Phytochemical Methods. Chapman and Hall, London. 1973. pp: 1.

12. Edward, D. C.; Kristin, R. M.; John, T. B.; Preston, H.; Linda, K.R.; Patrick, J. B.; David, W. H. R. Induction of inducible nitric oxide synthase by lipoarabinomannan of Mycobacterium tuberculosis. Infection and Immunity. 2001(30): 2001-2010.

13. Mukhopadhyay, S.; Srivastava, V. M. L.; Murthy, P. K.; Hasnain, S.E. Poorer NF- $\kappa$ B signaling by microfilariae in macrophages from $\mathrm{BALB} / \mathrm{c}$ mice affects their ability to produce cytotoxic levels of nitric oxide to kill microfilariae. FEBS Lett. 2004. (12): 275-280.

14. Jiang, B.; M. Haverty.; and P. Brecher. NAcetyl-L-cysteine enhances interleukin-1 $\beta$ induced nitric oxide synthase expression. Hypertension. 1999, (34):574-579.

15. Heitmeier, M. R.; A. L Scarim.; and J. A. Corbett. Double-stranded RNA-induced inducible Nitric-oxide Synthase expression and interleukin-1 release by murine macrophages requires NF- $\kappa \mathrm{B}$ activation. $J$. Biol. Chem. 1998, (273): 15301-15307.

16. Ignacio, S. R.; Ferreira, J. L.; Almeida, M. B.; Kubelka, C. F. Nitric oxide production by murine peritoneal macrophages in vitro and in vivo treated with Phyllanthus tenellus extracts. Journal of Ethnopharmacology. 2001.74. pp: 181-187.

17. Calixto, J.B.; Otuki, M.F.; Santos, A.R. Antiinflammatory compounds of plant origin. Part I. Action on arachidonic acid pathway, nitric oxide and nuclear factor kappa B (NF-kappa B). Planta Medica. 2003, (69): 973-983.

18. Ferrara, N. Vascular endothelial growth factor: molecular and biological aspects. Curr Top Microbiol, Immunol. 1999, (273) 1-30. 